\title{
Monitoring Interest in Herpes Zoster Vaccination: Analysis of Google Search Data
}

Elyse J Berlinberg ${ }^{1}$, BS; Michael S Deiner ${ }^{1,2}$, PhD; Travis C Porco ${ }^{1,2,3,4}, \mathrm{PhD}, \mathrm{MPH}$; Nisha R Acharya ${ }^{1,2,3,4}$, MD, MS

${ }^{1}$ Francis I Proctor Foundation, University of California, San Francisco, San Francisco, CA, United States

${ }^{2}$ Department of Ophthalmology, University of California, San Francisco, San Francisco, CA, United States

${ }^{3}$ Department of Epidemiology \& Biostatistics, University of California, San Francisco, San Francisco, CA, United States

${ }^{4}$ Institute for Global Health Sciences, University of California, San Francisco, San Francisco, CA, United States

\section{Corresponding Author:}

Nisha R Acharya, MD, MS

Francis I Proctor Foundation

University of California, San Francisco

513 Parnassus Ave, S309

San Francisco, CA, 94143-0412

United States

Phone: 14154768131

Fax: 14155022521

Email: nisha.acharya@ucsf.edu

\section{Abstract}

Background: A new recombinant subunit vaccine for herpes zoster (HZ or shingles) was approved by the United States Food and Drug Administration on October 20, 2017 and is expected to replace the previous live attenuated vaccine. There have been low coverage rates with the live attenuated vaccine (Zostavax), ranging from 12-32\% of eligible patients receiving the HZ vaccine.

Objective: This study aimed to provide insight into trends and potential reasons for interest in $\mathrm{HZ}$ vaccination.

Methods: Internet search data were queried from the Google Health application programming interface from $2004-2017$. Seasonality of normalized search volume was analyzed using wavelets and Fisher's g test.

Results: The search terms "shingles vaccine," "zoster vaccine," and "zostavax" all exhibited significant periodicity in the fall months $(P<.001)$, with sharp increases after recommendations for vaccination by public health-related organizations. Although the terms "shingles blisters," "shingles itch," "shingles rash," "skin rash," and "shingles medicine" exhibited statistically significant periodicities with a seasonal peak in the summer $(P<.001)$, the terms "shingles contagious," "shingles pain," "shingles treatment," and "shingles symptoms" did not reveal an annual trend.

Conclusions: There may be increased interest in HZ vaccination during the fall and after public health organization recommendations are broadcast. This finding points to the possibility that increased awareness of the vaccine through public health announcements could be evaluated as a potential intervention for increasing vaccine coverage.

(JMIR Public Health Surveill 2018;4(2):e10180) doi: 10.2196/10180

\section{KEYWORDS}

herpes zoster; vaccination; Internet; periodicity; Google Trends; infodemiology

\section{Introduction}

One in three Americans will experience shingles (herpes zoster; $\mathrm{HZ}$ ) in their lifetime, which may lead to extremely painful postherpetic neuralgia [1]. HZ of the eye, or herpes zoster ophthalmicus, is the second most common location of $\mathrm{HZ}$ and can lead to blindness [1-4]. On October 20, 2017, the United States Food and Drug Administration (FDA) approved Shingrix (GlaxoSmithKline), a new recombinant subunit vaccine for $\mathrm{HZ}$
[5]. The recombinant subunit vaccine has been shown to have over $95 \%$ efficacy in clinical trials and is now Centers for Disease Control and Prevention (CDC)-preferred over the live attenuated vaccine Zostavax (Merck) released in 2006 [6,7]. However, many lessons can be learned from this first experience with $\mathrm{HZ}$ vaccination. Despite showing over $51 \%$ and $70 \%$ efficacy in adults over age 50 and 60, respectively, the live attenuated vaccine had low coverage rates: studies estimate between $12 \%$ and $32 \%$ of vaccine-eligible adults have received 
the $\mathrm{HZ}$ vaccine [8-10]. Many possible contributing factors to the low vaccination rate have been proposed, including high cost, a lack of consensus on vaccine recommendation, waning efficacy, supply issues, and general lack of awareness of the vaccine and its benefits [11-20]. Influences on general awareness and interest in the $\mathrm{HZ}$ vaccine are poorly understood, and if known they could be utilized in designing more effective public health efforts to increase $\mathrm{HZ}$ immunizations. We sought to identify some of the factors affecting public interest in $\mathrm{HZ}$ and its vaccine.

Over the past several years, analysis of social media and search data has been of increasing interest in public health efforts [21,22]. This approach has been used to estimate disease incidence, identify and predict potential epidemic outbreaks, assess general understanding of a disease, and gauge public interest in a health-related topic [23-33]. In this study, we analyzed Google Search data to assess past trends in public interest for $\mathrm{HZ}$ vaccination in an attempt to better understand what factors may impact $\mathrm{HZ}$ vaccine utilization. These findings can inform possible future interventions that could help increase $\mathrm{HZ}$ vaccine awareness and uptake for eligible patients.

\section{Methods}

Search data were obtained from the Google Health application programming interface (API; Alphabet, Inc) using specific search terms related to $\mathrm{HZ}$ or $\mathrm{HZ}$ vaccination ("shingles vaccine," "zoster vaccine," "Zostavax," "medicare vaccine," "shingrix," "shingles blisters," "shingles itch," "shingles rash," "skin rash," "shingles medicine," "eye shingles," "shingles contagious," "shingles pain," "shingles treatment," and "shingles symptoms") and negative control search terms ("roof shingle," "roof shingles," "roof repair," and "roof symptoms"). Unless otherwise specified, all API queries limited results to searches made with a United States geolocation. For each term, the Google Health API was queried for all search data between January 1, 2004 and December 1, 2017. Weekly 2017 data were obtained from the public Google Trends site, which automatically normalizes searches as a relative volume, reported as a number between 0 and 1 . Google API data is presented in a grouped fashion to protect privacy per Google API data user requirements.

We assessed periodicity in searches using the weekly or monthly relative intensity of the search data queried between January 1, 2011 and December 31, 2016. Significance of periodicity was tested using Fisher's g test [34]. To compare seasonal timing between different search terms, we fit trigonometric regression models. We used the equation:

$$
y=c_{0}+c_{1} t+c_{2} t^{2}+\sum_{i=1}^{8}\left(b_{i} \sin (i \omega t)+a_{i} \cos (i \omega t)\right)
$$

and used time series bootstrap [35] to test the null hypothesis that the difference in the phase angle $\arctan 1 / a_{1}$ for the annual terms was zero. A fixed width of 4 was chosen for bootstrap resampling of residuals, with sensitivity analysis using a width of 2 and 8 .

Time-frequency analysis was conducted using Morlet wavelets [36], which were estimated using the WaveletComp package in R. A $P$-value of less than .05 was considered significant. All statistical tests were conducted in $\mathrm{R}$ version 3.3 for MacIntosh (The R Foundation for Statistical Computing, Vienna, Austria).

\section{Results}

\section{Seasonal Patterns of Searches Related to Herpes Zoster Vaccination}

Google Health API was queried for all searches related to HZ vaccination between January 1, 2011 and December 31, 2016. The relative frequency of searches for the terms "shingles vaccine," "zoster vaccine," and "zostavax" are shown in Figure 1. Trend lines for these terms exhibited a significant annual periodicity with a maximum in the fall $(P<.001$ by Fisher's $g$ test).

Our initial hypothesis on the possible cause of this seasonal trend is that it is related to insurance utilization. Since deductibles are generally reset on January $1^{\text {st }}$ in American health insurance systems, it could be that more $\mathrm{HZ}$ vaccine-eligible patients would seek out this elective immunization in the last few months of the year. Furthermore, the majority of patients receiving the $\mathrm{HZ}$ vaccine are Medicare-eligible. The open enrollment period for Medicare Advantage and the Medicare Drug Plan runs between mid-October and December [37]. Newly eligible patients may look online for ways to apply their new insurance policy immediately after they enroll. To test this hypothesis, we assessed the seasonality of searches for "medicare" (Figure 1, blue) and "medicare vaccine" (data not shown). These terms revealed a similar annual cycle as "shingles vaccine," "zoster vaccine," and "Zostavax," with a significant seasonal trend peaking in the fall $(P<.001$ for both terms, Fisher's g test).

In addition, it has been shown that covaccination for influenza and $\mathrm{HZ}$ is safe [38]. One could also hypothesize that the surge in interest for the $\mathrm{HZ}$ vaccine may be linked to the flu season. We assessed periodicity for searches for "flu vaccine" and found that it also exhibited a pronounced annual cycle $(P<.001$, Fisher's g test) with a peak in the fall (data not shown).

We also considered that the seasonal pattern may be related to commercial advertising for the vaccine. Merck produced two widely viewed commercials featuring a popular former National Football League quarterback, initially released in September 2014 and 2015 [39,40]. These commercials may have led individuals to then search online for more information about the vaccine. However, this does not provide a complete explanation of the seasonal trend; Merck has also released other shingles-related commercials in February, April, May, June, July, and August. 
Figure 1. Smoothed Google searches for herpes zoster vaccination-related terms from 2011-2017, normalized as relative search volume (0-1.0). Smoothing was conducted using Morlet wavelet denoising (lower period of 4 weeks, upper period of 128 weeks, omitting terms nonsignificant at the $\mathrm{P}=.05$ level).

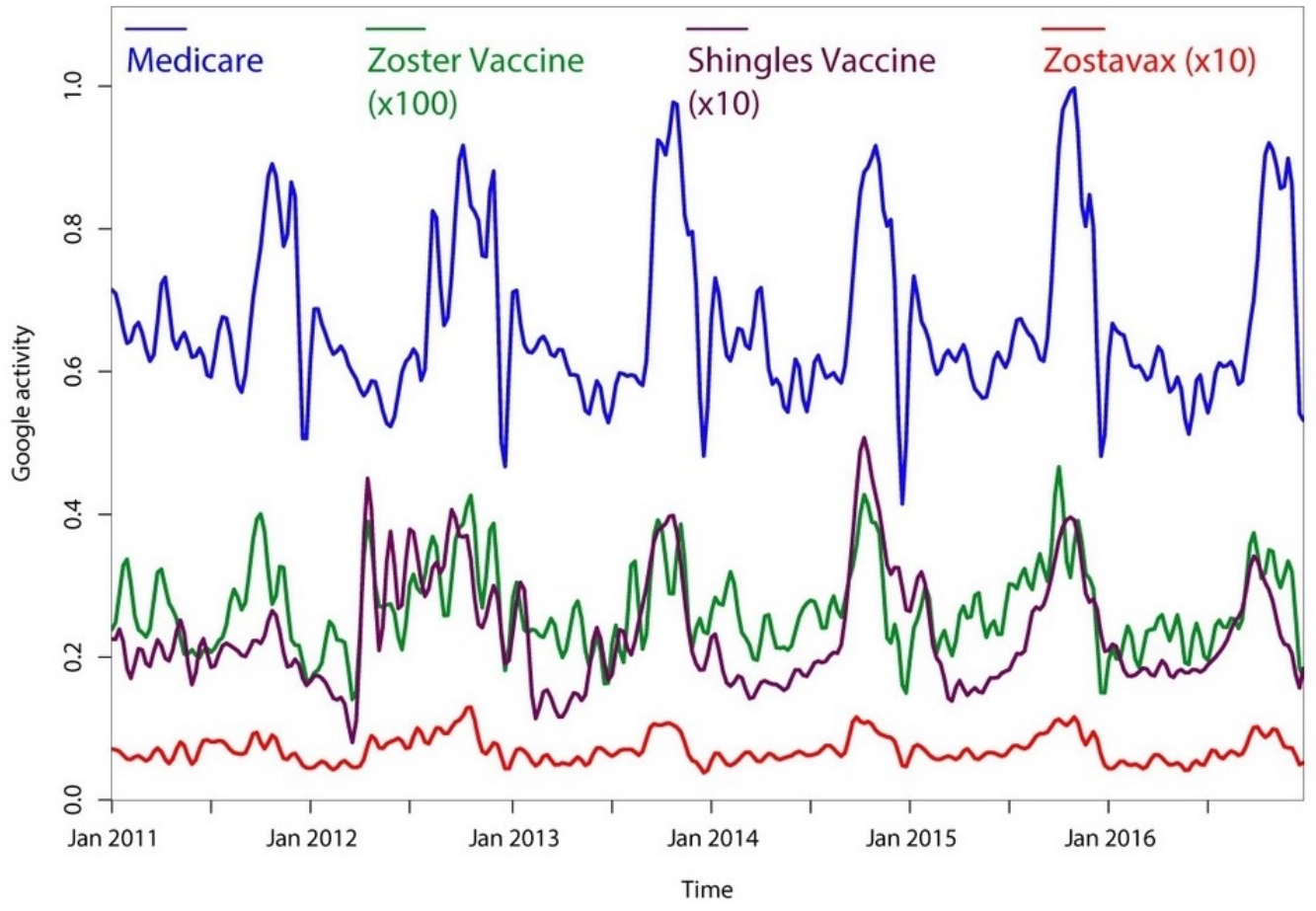

\section{Significant Events in Herpes Zoster Vaccination}

In our analysis for a seasonal trend in $\mathrm{HZ}$ vaccination, we noted that there were certain time points at which the overall volume of searches for vaccination-related topics sharply increased. We inferred that these time points may correspond with key dates in the development, approval, and extension of the HZ vaccine. The FDA approved the live attenuated vaccine (Zostavax) for US patients aged 60 or older on May 25, 2006 and extended its recommendation to patients aged 50 or older on March 25, 2011 $[41,42]$. Furthermore, the CDC issued its recommendation for the live attenuated vaccine in adults aged 60 or older on October 25, 2006 [43]. Google Trends data were used to estimate US public interest in the vaccine before and after these key dates (Figure 2, red). Between April 2006 and May 2006, Google searches for the term "zostavax" increased 16-fold. Google searches for "zostavax" reached a maximum in November 2006, shortly after the CDC's recommendation was broadcast. Google searches for "zostavax" decreased over time after the FDA and CDC recommendations and increased again around the date of the FDA extension in March 2011, when searches increased 1.5 -fold over the subsequent 6 months and 2-fold in the following year.

The trend in searches for "zostavax" in the United States was compared to the trend in Canada, where the National Advisory Committee on Immunization (NACI) first recommended the live attenuated vaccine for patients 60 years of age or older in January 2010, and then extended this recommendation to patients 50 years of age or older in January 2014 [44,45]. In Canada (Figure 2, green), searches for "zostavax" increased 2 -fold just before the initial offering of the vaccine in 2010, but their maximum did not occur until 2014, when the NACI extended its recommendation to people between 50-59 years of age. US searches for "zostavax" were also compared to searches in the United Kingdom, where National Health Service England first offered the live attenuated vaccine through its Shingles Immunisation Programme in September 2013 [46]. Google searches for "zostavax" in the United Kingdom (Figure 2, blue) reached a maximum in October 2013.

The FDA approved the new recombinant subunit vaccine (Shingrix) on October 20, 2017 [5]. In light of this recent event, we additionally analyzed Google searches before and after this approval. The results can be found in Figure 3. After FDA approval, Google searches for the term "shingrix" increased over 6-fold with an accompanying 2-fold increase in searches for the term "shingles vaccine" and 1.5-fold increase in searches for "zoster vaccine."

\section{Findings for Other Herpes Zoster-Related Terms}

While this study primarily focused on trends in $\mathrm{HZ}$ vaccination, we also used the same techniques to explore trends for other HZ-related terms that are less directly associated with vaccination, including "shingles contagious" and "shingles medicine" (Figure 4); "shingles symptoms," "shingles blisters," "shingles rash," and "eye shingles" (Figure 5); and "skin rash," "shingles itch," "shingles pain," and "shingles treatment" (data not shown). Figure 4 also illustrates trends in searches for the possible covariate "roof shingles" that also exhibits an annual periodicity but has a slightly shifted peak season compared to the terms "shingles contagious" and "shingles medicine" $(P<.001)$. Although we did not find sharp increases in searches for these other HZ-related terms, we did find a periodicity for many of them. The terms "shingles blisters," "shingles itch," "shingles medicine," "skin rash," and "shingles rash" showed a statistically significant annual trend (see Table 1). The terms "shingles contagious," "eye shingles," and "shingles pain" 
showed no evidence of periodicity. The term "shingles symptoms" showed a highly significant periodicity with a 20 -week cycle $(P<.001)$. The term "shingles treatment" showed a similar 20-week periodicity that did not reach significance
$(P=.11)$ according to Fisher's g test (although Morlet wavelet decomposition revealed a highly significant periodicity which began in early 2012).

Figure 2. Trends in Google searches for herpes zoster vaccination-related terms from 2004-2017 for the United States, Canada, and the United Kingdom, shown using 3-point median smooth. Trends are annotated for key dates in live attenuated vaccine recommendation.

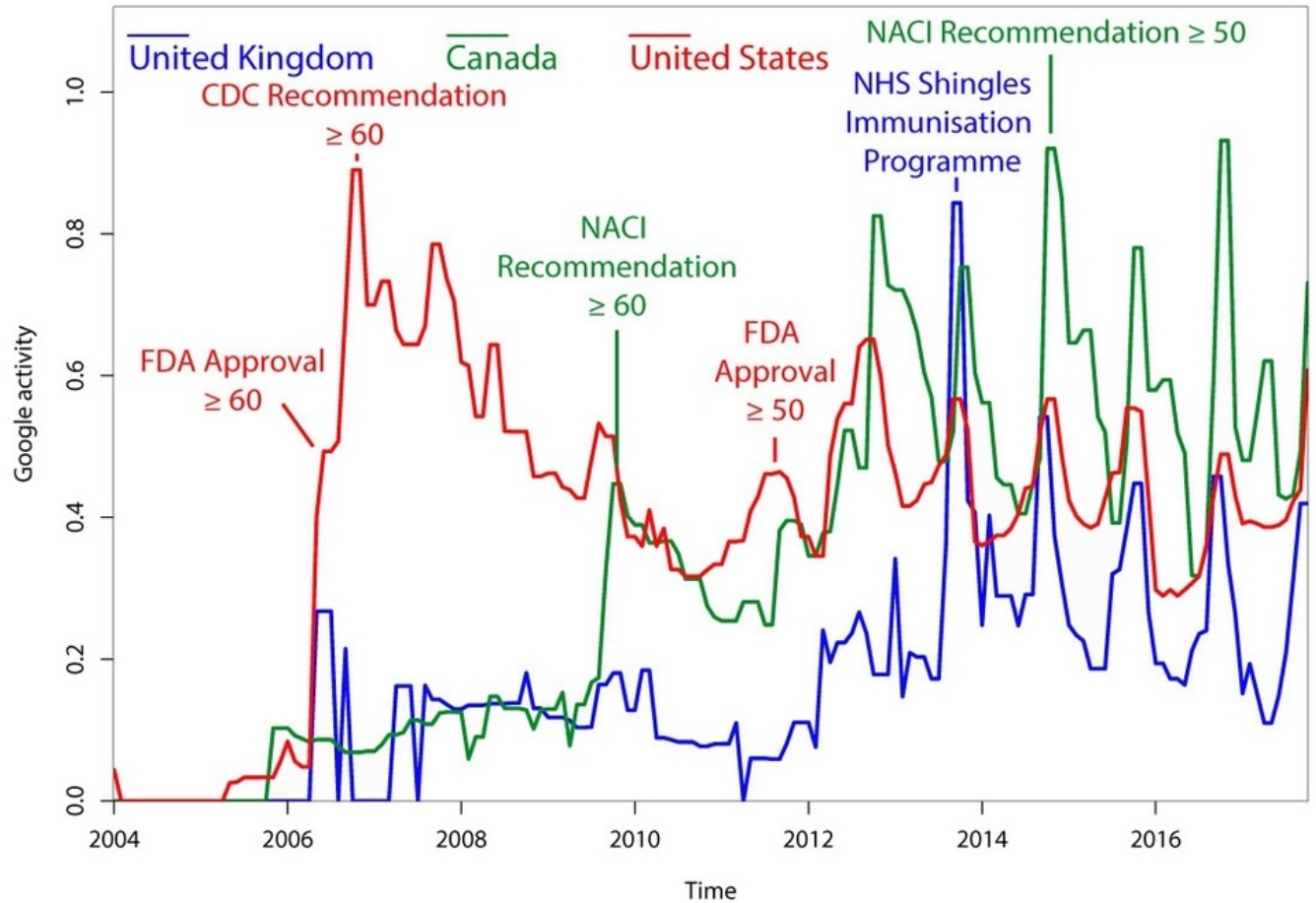

Figure 3. Google search data for herpes zoster vaccination-related terms and the term "shingrix" around its United States Food and Drug Administration approval on October 20, 2017. The 2017 weekly data used for this figure was retrieved from the public Google Trends website, not the Google Health application programming interface.

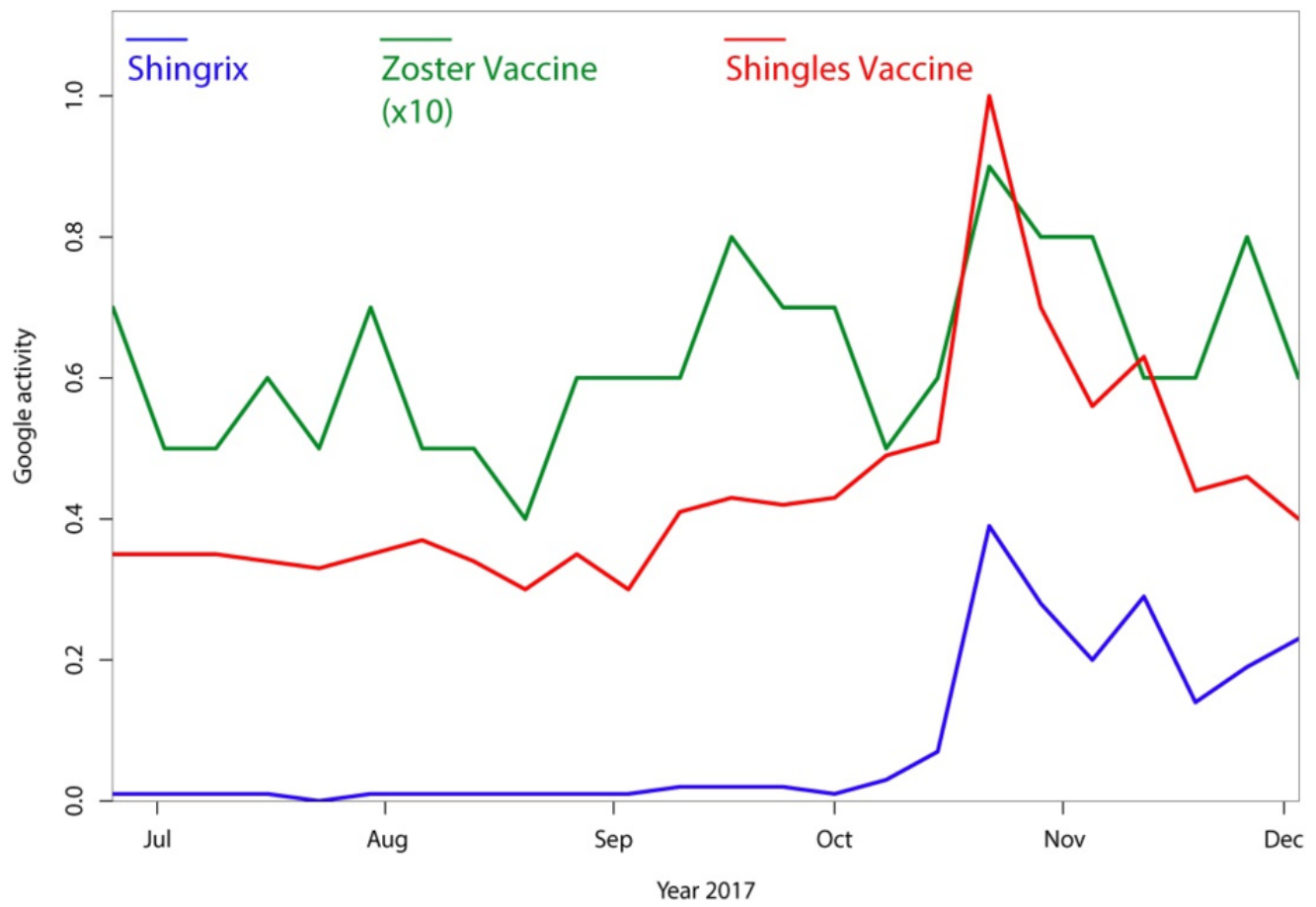


Figure 4. Smoothed Google searches for "shingles contagious," "roof shingles," and "shingles medicine" from 2011-2017, normalized as relative search volume (0-1.0). Searches for "roof shingles" are shown to illustrate seasonality of an unrelated search for "shingles." Smoothing was conducted as in Figure 1.

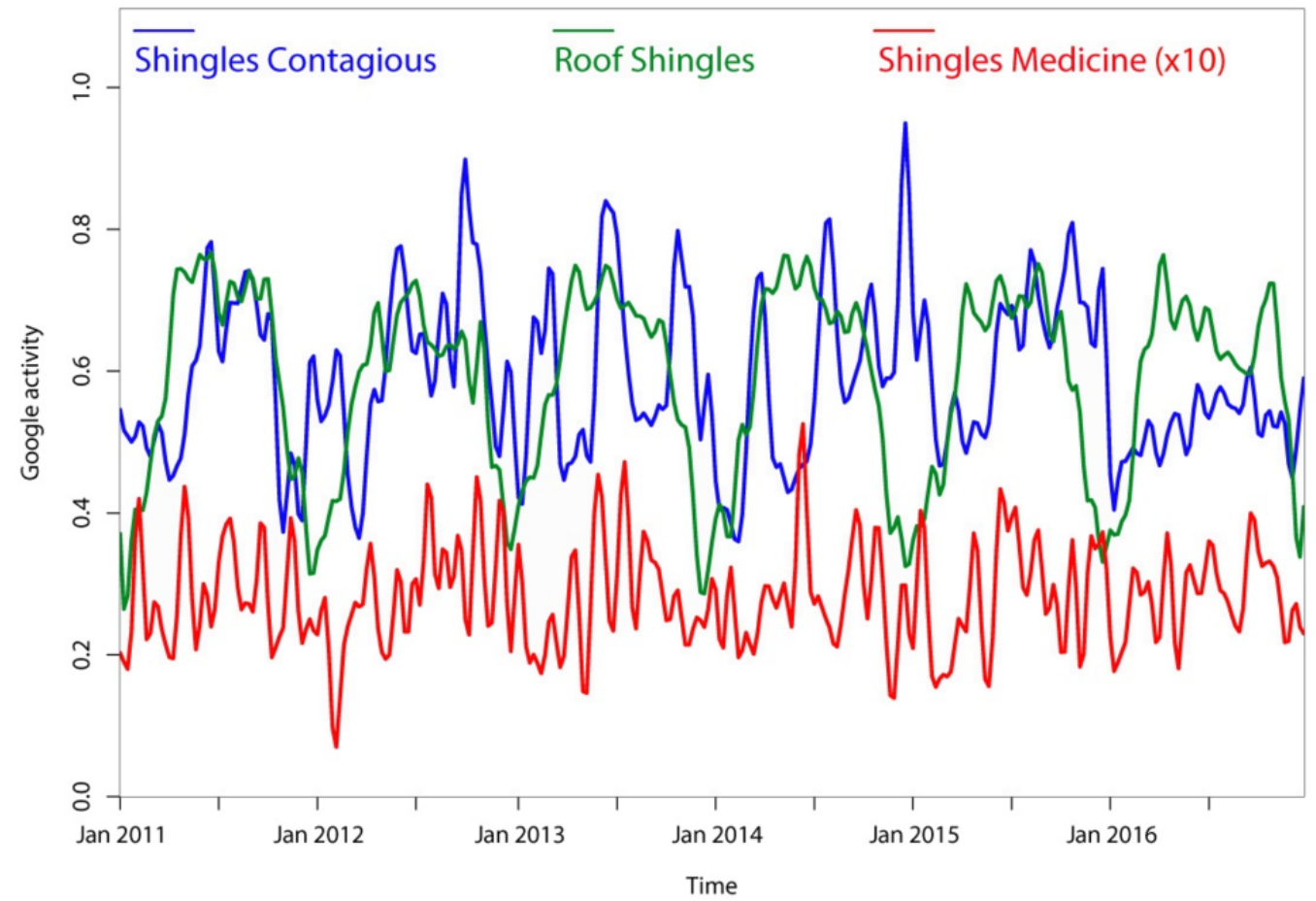

Figure 5. Smoothed Google searches for "shingles symptoms," "shingles blisters," "shingles rash," and "eye shingles" from 2011-2017, normalized as relative search volume (0-1.0).

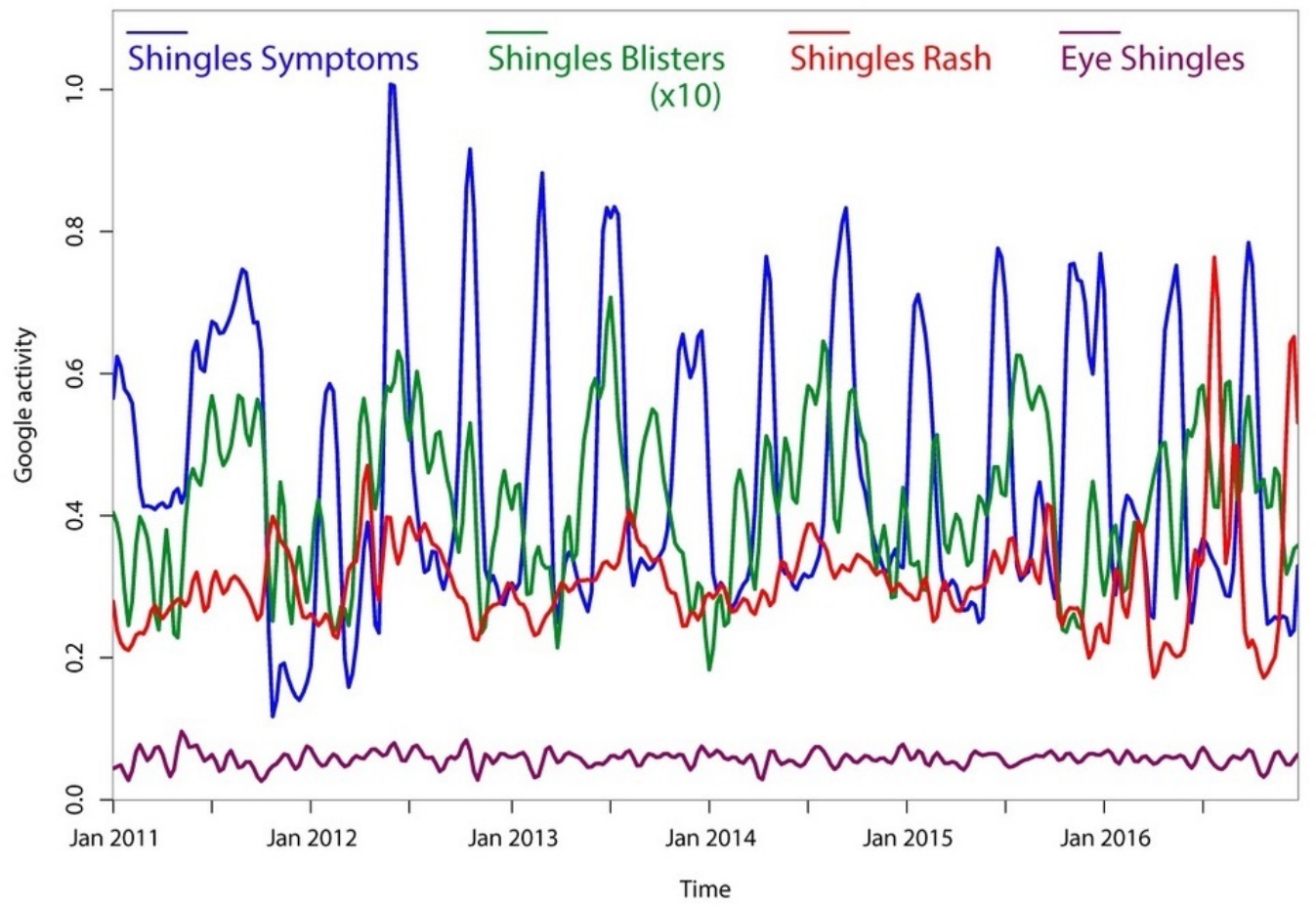


Table 1. Periodicity of searches for herpes zoster-related terms.

\begin{tabular}{llll}
\hline Search Term & Frequency (cycles per year) & Peak Season(s) & Fisher's g \\
\hline Shingles Blisters & 1 & Summer & $<.001$ \\
Shingles Itch & 1 & Summer & $<.001$ \\
Shingles Rash & 1 & Summer & $<.001$ \\
Skin Rash & 1 & Summer & $<.001$ \\
Shingles Medicine & 1 & Summer & $<.001$ \\
Eye Shingles & 1 & N/A & .88 \\
Shingles Contagious & $<1$ & N/A & $<.001$ \\
Shingles Pain & $<1$ & N/A & .01 \\
Shingles Treatment & 2.6 & N/A & .11 \\
Shingles Symptoms & 2.6 & N/A & $<.001$ \\
\hline
\end{tabular}

${ }^{\mathrm{a}} \mathrm{N} / \mathrm{A}$ : not applicable.

\section{Discussion}

\section{Principal Findings}

Our current analysis of historic changes and seasonal patterns of public search interest over time related to the $\mathrm{HZ}$ vaccine identified a highly significant annual trend for searches related to vaccination, which appeared in part to be related to utilization of Medicare benefits, covaccination with the influenza vaccine, and advertising campaigns. This finding provides us with a better understanding of public interest in the $\mathrm{HZ}$ vaccine, which can be applied to informing future efforts to increase vaccine coverage.

Our results also suggest that public interest in a vaccine may be significantly affected by recommendations from health-related governmental departments. In the United States, United Kingdom, and Canada, a spike in search interest occurred in each country for vaccine-related terms soon after a recommendation by a health-related governmental organization was broadcast. With this in mind, it may be helpful to increase vaccine production or clinical stocks in anticipation of the increase in vaccine interest caused by these announcements. This factor is particularly important given the recent release of the new recombinant subunit vaccine. When the live attenuated vaccine was first released, there was some delay in vaccination efforts due to an insufficient supply of the vaccine [13]. The recent release of the recombinant subunit vaccine should not fall into the same trap, and vaccine availability could be increased accordingly to anticipate the likely increase in interest after any FDA or CDC announcements.

Finally, we report on a possible seasonality for interest in $\mathrm{HZ}$ as measured by an increase in Google search intensity in the summer. While trends in Google searches could be representative of trends in $\mathrm{HZ}$ incidence, there have been mixed reports about whether or not $\mathrm{HZ}$ is seasonal. Many studies have been published on the topic, ranging from reports of a single practice to regional health registries [47-58]. Six of these studies found that $\mathrm{HZ}$ exhibits a statistically significant seasonality, while two found that $\mathrm{HZ}$ incidence varies by season, but this trend was either not significant or its significance was not tested. All of the studies that reported a seasonal trend found an increase of $\mathrm{HZ}$ cases in the summer, which could explain the increase in interest for $\mathrm{HZ}$ vaccination in the summer. However, Google searches are only representative of interest in a topic and do not necessarily mean that a person has the disease they have searched for. Since the seasonality of $\mathrm{HZ}$ has been inconsistently characterized, we believe that this trend should be evaluated further utilizing a large health-specific dataset.

\section{Limitations}

The use of social media and Internet search data to assess health matters has become more useful in recent years, but its methods come with limitations including the following for our current study. Google API data are reported as a normalized relative volume and can over-represent fluctuations in searches for terms with low post volumes. Second, Google Searches also estimate interest in a given topic, but not the follow through of getting vaccinated. Likewise, the periodicity of searches for $\mathrm{HZ}$ vaccination may not correspond to trends in actual utilization of the vaccine. As mentioned previously, our findings could benefit from validation using large administrative clinical datasets.

\section{Conclusions}

Google searches about $\mathrm{HZ}$ vaccination exhibit an annual periodicity in the fall and significant peaks after recommendations from large public health organizations are broadcast. Given previous issues with $\mathrm{HZ}$ vaccine availability and coverage, these trends may help predict when to increase supply of the new recombinant subunit vaccine to meet changes in demand, and when to increase awareness to improve coverage. 


\section{Acknowledgments}

This work was supported in part by grants 1R01EY024608 and 1R01EY028739 from the National Institutes of Health National Eye Institute (NIH-NEI), grant EY002162 (Core Grant for Vision Research) from the NIH-NEI, and an Unrestricted Grant from Research to Prevent Blindness.

\section{Conflicts of Interest}

None declared

\section{References}

1. Dworkin RH, Johnson RW, Breuer J, Gnann JW, Levin MJ, Backonja M, et al. Recommendations for the management of herpes zoster. Clin Infect Dis 2007 Jan 01;44 Suppl 1:S1-26. [doi: 10.1086/510206] [Medline: 17143845]

2. Liesegang TJ. Herpes zoster ophthalmicus natural history, risk factors, clinical presentation, and morbidity. Ophthalmology 2008 Feb;115(2 Suppl):S3-12. [doi: 10.1016/j.ophtha.2007.10.009] [Medline: 18243930]

3. Borkar DS, Tham VM, Esterberg E, Ray KJ, Vinoya AC, Parker JV, et al. Incidence of herpes zoster ophthalmicus: results from the Pacific Ocular Inflammation Study. Ophthalmology 2013 Mar;120(3):451-456 [FREE Full text] [doi: 10.1016/j.ophtha.2012.09.007] [Medline: 23207173]

4. Ragozzino MW, Melton LJ, Kurland LT, Chu CP, Perry HO. Population-based study of herpes zoster and its sequelae. Medicine (Baltimore) 1982 Sep;61(5):310-316. [Medline: 6981045]

5. Gruber M. United States Food and Drug Administration. 2017 Oct 20. BLA approval - zoster vaccine recombinant URL: https://www.fda.gov/downloads/BiologicsBloodVaccines/Vaccines/ApprovedProducts/UCM581750.pdf [accessed 2017-12-16] [WebCite Cache ID 6xxvVGFcq]

6. Lal H, Cunningham AL, Godeaux O, Chlibek R, Diez-Domingo J, Hwang S, ZOE-50 Study Group. Efficacy of an adjuvanted herpes zoster subunit vaccine in older adults. N Engl J Med 2015 May 28;372(22):2087-2096. [doi: 10.1056/NEJMoa1501184] [Medline: 25916341]

7. United States Centers for Disease Control and Prevention. 2018. Shingles (herpes zoster) URL: https://www.cdc.gov/ shingles/vaccination.html [accessed 2018-02-02] [WebCite Cache ID 6yYPw24AY]

8. Williams WW, Lu P, O'Halloran A, Kim DK, Grohskopf LA, Pilishvili T, Centers for Disease Control and Prevention. Surveillance of vaccination coverage among adult populations - United States, 2014. MMWR Surveill Summ 2016 Feb 5;65(1):1-36. [doi: 10.15585/mmwr.ss6501a1] [Medline: 26844596]

9. Lu P, O'Halloran A, Williams WW, Harpaz R. National and state-specific shingles vaccination among adults aged $\geq 60$ Years. Am J Prev Med 2017 Mar;52(3):362-372 [FREE Full text] [doi: 10.1016/j.amepre.2016.08.031] [Medline: 27720342]

10. Hernandez PO, Javed S, Mendoza N, Lapolla W, Hicks LD, Tyring SK. Family history and herpes zoster risk in the era of shingles vaccination. J Clin Virol 2011 Dec;52(4):344-348. [doi: 10.1016/j.jcv.2011.08.014] [Medline: 21924676]

11. Harpaz R, Ortega-Sanchez IR, Seward JF, Advisory Committee on Immunization Practices (ACIP) Centers for Disease Control and Prevention (CDC). Prevention of herpes zoster: recommendations of the Advisory Committee on Immunization Practices (ACIP). MMWR Recomm Rep 2008 Jun 06;57(RR-5):1-30 [FREE Full text] [Medline: 18528318]

12. Hales CM, Harpaz R, Ortega-Sanchez I, Bialek SR, Centers for Disease Control and Prevention (CDC). Update on recommendations for use of herpes zoster vaccine. MMWR Morb Mortal Wkly Rep 2014 Aug 22;63(33):729-731 [FREE Full text] [Medline: 25144544]

13. United States Centers for Disease Control and Prevention. 2007 May 11. Morbidity and mortality weekly report. Notice to readers: supply of vaccines containing varicella-zoster virus URL: https://www.cdc.gov/mmwr/preview/mmwrhtml/ mm5618a6.htm [accessed 2017-12-21] [WebCite Cache ID 6xNbmcUpo]

14. Cohen E. Prevention of herpes zoster: we need to do better. JAMA Ophthalmol 2013 Mar;131(3):396-398. [doi: 10.1001/jamaophthalmol.2013.588] [Medline: 23494045]

15. Jung JJ, Elkin ZP, Li X, Goldberg JD, Edell AR, Cohen MN, et al. Increasing use of the vaccine against zoster through recommendation and administration by ophthalmologists at a city hospital. Am J Ophthalmol 2013 May;155(5):787-795. [doi: 10.1016/j.ajo.2012.11.022] [Medline: 23394910]

16. Hurley LP, Bridges CB, Harpaz R, Allison MA, O'Leary ST, Crane LA, et al. Physician attitudes toward adult vaccines and other preventive practices, United States, 2012. Public Health Rep 2016;131(2):320-330 [FREE Full text] [doi: 10.1177/003335491613100216] [Medline: 26957667]

17. Otsuka SH, Tayal NH, Porter K, Embi PJ, Beatty SJ. Improving herpes zoster vaccination rates through use of a clinical pharmacist and a personal health record. Am J Med 2013 Sep;126(9):832.e1-832.e6 [FREE Full text] [doi: 10.1016/j.amjmed.2013.02.018] [Medline: 23830534]

18. Bryan AR, Liu Y, Kuehl PG. Advocating zoster vaccination in a community pharmacy through use of personal selling. J Am Pharm Assoc (2003) 2013;53(1):70-77. [Medline: 23636159]

19. Opstelten W, van Essen GA, Hak E. Determinants of non-compliance with herpes zoster vaccination in the community-dwelling elderly. Vaccine 2009 Jan 07;27(2):192-196. [doi: 10.1016/j.vaccine.2008.10.047] [Medline: 18996427] 
20. Teeter BS, Garza KB, Stevenson TL, Williamson MA, Zeek ML, Westrick SC. Factors associated with herpes zoster vaccination status and acceptance of vaccine recommendation in community pharmacies. Vaccine 2014 Sep 29;32(43):5749-5754. [doi: 10.1016/j.vaccine.2014.08.040] [Medline: 25171848]

21. Eysenbach G. Infodemiology and infoveillance: tracking online health information and cyberbehavior for public health. Am J Prev Med 2011 May;40(5 Suppl 2):S154-S158. [doi: 10.1016/j.amepre.2011.02.006] [Medline: 21521589]

22. Ginsberg J, Mohebbi MH, Patel RS, Brammer L, Smolinski MS, Brilliant L. Detecting influenza epidemics using search engine query data. Nature 2009 Feb 19;457(7232):1012-1014. [doi: 10.1038/nature07634] [Medline: 19020500]

23. Deiner MS, Lietman TM, McLeod SD, Chodosh J, Porco TC. Surveillance tools emerging from search engines and social media data for determining eye disease patterns. JAMA Ophthalmol 2016 Sep 01;134(9):1024-1030 [FREE Full text] [doi: 10.1001/jamaophthalmol.2016.2267] [Medline: 27416554]

24. Kang M, Zhong H, He J, Rutherford S, Yang F. Using Google Trends for influenza surveillance in South China. PLoS One 2013;8(1):e55205 [FREE Full text] [doi: 10.1371/journal.pone.0055205] [Medline: 23372837]

25. Hiller KM, Stoneking L, Min A, Rhodes SM. Syndromic surveillance for influenza in the emergency department-a systematic review. PLoS One 2013;8(9):e73832 [FREE Full text] [doi: 10.1371/journal.pone.0073832] [Medline: 24058494]

26. Wang H, Chen D, Yu H, Chen Y. Forecasting the incidence of dementia and dementia-related outpatient visits with google trends: evidence from Taiwan. J Med Internet Res 2015 Nov 19;17(11):e264 [FREE Full text] [doi: 10.2196/jmir.4516] [Medline: 26586281]

27. Dugas AF, Jalalpour M, Gel Y, Levin S, Torcaso F, Igusa T, et al. Influenza forecasting with Google Flu Trends. PLoS One 2013;8(2):e56176 [FREE Full text] [doi: 10.1371/journal.pone.0056176] [Medline: 23457520]

28. Malik MT, Gumel A, Thompson LH, Strome T, Mahmud SM. "Google flu trends" and emergency department triage data predicted the 2009 pandemic H1N1 waves in Manitoba. Can J Public Health 2011;102(4):294-297. [Medline: 21913587]

29. Schootman M, Toor A, Cavazos-Rehg P, Jeffe DB, McQueen A, Eberth J, et al. The utility of Google Trends data to examine interest in cancer screening. BMJ Open 2015 Jun 08;5(6):e006678 [FREE Full text] [doi: 10.1136/bmjopen-2014-006678] [Medline: 26056120]

30. Moccia M, Palladino R, Falco A, Saccà F, Lanzillo R, Brescia MV. Google Trends: new evidence for seasonality of multiple sclerosis. J Neurol Neurosurg Psychiatry 2016 Dec;87(9):1028-1029. [doi: 10.1136/jnnp-2016-313260] [Medline: 27083532]

31. Bragazzi NL, Bacigaluppi S, Robba C, Nardone R, Trinka E, Brigo F. Infodemiology of status epilepticus: a systematic validation of the Google Trends-based search queries. Epilepsy Behav 2016 Feb;55:120-123. [doi:

10.1016/j.yebeh.2015.12.017] [Medline: 26773681]

32. Pollett S, Wood N, Boscardin WJ, Bengtsson H, Schwarcz S, Harriman K, et al. Validating the use of Google Trends to enhance pertussis surveillance in California. PLoS Curr 2015 Oct 19;7 [FREE Full text] [doi: 10.1371/currents.outbreaks.7119696b3e7523faa4543faac87c56c2] [Medline: 26543674]

33. Foroughi F, Lam AK, Lim MSC, Saremi N, Ahmadvand A. "Googling" for cancer: an infodemiological assessment of online search interests in Australia, Canada, New Zealand, the United Kingdom, and the United States. JMIR Cancer 2016 May 04;2(1):e5 [FREE Full text] [doi: 10.2196/cancer.5212] [Medline: 28410185]

34. Fisher RA. Tests of significance in harmonic analysis. Proc Royal Soc A 1929 Aug 01;125(796):54-59. [doi: 10.1098/rspa.1929.0151]

35. Kreiss J, Lahiri S. Bootstrap methods for time series. In: Subba Rao T, Subba Rao S, Rao CR, editors. Time Series Analysis: Methods and Applications, Volume 30. North Holland: Elsevier; 2012:3-26.

36. Pereyra M, Ward L. Harmonic Analysis: From Fourier to Wavelets. Park City, UT: American Mathematical Society; 2012.

37. United States Centers for Medicare \& Medicaid Services. 2018. Joining a health or drug plan URL: https://www.medicare.gov/ sign-up-change-plans/ [accessed 2018-04-09] [WebCite Cache ID 6yYQTuWAi]

38. Kerzner B, Murray AV, Cheng E, Ifle R, Harvey PR, Tomlinson M, et al. Safety and immunogenicity profile of the concomitant administration of ZOSTAVAX and inactivated influenza vaccine in adults aged 50 and older. J Am Geriatr Soc 2007 Oct;55(10):1499-1507. [doi: 10.1111/j.1532-5415.2007.01397.x] [Medline: 17908055]

39. iSpot.tv. 2014. Merck TV commercial, 'Football Legend' featuring Terry Bradshaw URL: https://www.ispot.tv/ad/7CpH/ merck-football-legend-featuring-terry-bradshaw [accessed 2018-03-16] [WebCite Cache ID 6xxulxb91]

40. iSpot.tv. 2015. Merck TV commercial, 'Surprise Door Knock' featuring Terry Bradshaw URL: https://www.ispot.tv/ad/ 7UEu/merck-surprise-door-knock-featuring-terry-bradshaw [accessed 2018-03-16] [WebCite Cache ID 6xxuuHAYn]

41. Baylor N. United States Food and Drug Administration. 2006 May 25. Approval Letter - Zostavax URL: http://wayback. archive-it.org/7993/20170723093336/https://www.fda.gov/BiologicsBloodVaccines/Vaccines/ApprovedProducts/ucm132873. htm [accessed 2017-12-03] [WebCite Cache ID 6xxv4LuJy]

42. Agger PE, Sun W, United States Food and Drug Administration. Summary Basis for Regulatory Action. 2011. URL: https:/ /wayback.archive-it.org/7993/20170404184105/https://www.fda.gov/downloads/BiologicsBloodVaccines/Vaccines/ ApprovedProducts/UCM249230.pdf [accessed 2018-03-16] [WebCite Cache ID 6xxvBM1cQ]

43. United States Centers for Disease Control and Prevention. 2006. Press release: CDC's advisory committee recommends "shingles" vaccination URL: https://www.cdc.gov/media/pressrel/r061026.htm [accessed 2018-02-20] [WebCite Cache ID $6 \mathrm{xNc} 2 \mathrm{woaD}]$ 
44. National Advisory Committee on Immunization. An Advisory Committee Statement (ACS). National Advisory Committee on Immunization (NACI). Statement on recommended use of pneumococcal conjugate vaccine. Can Commun Dis Rep 2002 Jan 15;28(ACS-2):1-32 [FREE Full text] [Medline: 12728645]

45. National Advisory Committee on Immunization. Public Health Agency of Canada. 2014 Jan. An Advisory Committee Statement (ACS) National Advisory Committee on Immunization (NACI): Update on the Use of the Herpes Zoster Vaccine URL: https://www.canada.ca/content/dam/phac-aspc/documents/services/publications/healthy-living/ update-use-herpes-zoster-vaccine/hzv-vcz-eng.pdf [accessed 2017-12-10] [WebCite Cache ID 6yYOBsAqc]

46. Immunisation Implementation \& Planning Public Health England. Shingles Immunisation Programm. 2013 Apr. Public health functions to be exercised by NHS England: Service Specification URL: https://www.gov.uk/government/uploads/ system/uploads/attachment_data/file/192971/S7A_VARIATION_2013-14_FINAL_130417.pdf [accessed 2017-12-03] [WebCite Cache ID 6xxu39g02]

47. Glynn C, Crockford G, Gavaghan D, Cardno P, Price D, Miller J. Epidemiology of shingles. J R Soc Med 1990 Oct;83(10):617-619 [FREE Full text] [Medline: 1962821]

48. Gallerani M, Manfredini R. Correspondence: seasonal variation in herpes zoster infection. Br J Dermatol 2000;142:588. [doi: 10.1046/j.1365-2133.2000.03400.x]

49. Termorshuizen F, Hogewoning AA, Bouwes BJN, Goettsch WG, de Fijter JW, van Loveren H. Skin infections in renal transplant recipients and the relation with solar ultraviolet radiation. Clin Transplant 2003 Dec;17(6):522-527. [Medline: $\underline{14756268]}$

50. $\mathrm{Wu} \mathrm{P,} \mathrm{Wu} \mathrm{HI,} \mathrm{Chou} \mathrm{T,} \mathrm{Sung} \mathrm{F.} \mathrm{Varicella} \mathrm{vaccination} \mathrm{alters} \mathrm{the} \mathrm{chronological} \mathrm{trends} \mathrm{of} \mathrm{herpes} \mathrm{zoster} \mathrm{and} \mathrm{varicella.} \mathrm{PLoS}$ One 2013;8(10):e77709 [FREE Full text] [doi: 10.1371/journal.pone.0077709] [Medline: 24204928]

51. Zak-Prelich M, Borkowski JL, Alexander F, Norval M. The role of solar ultraviolet irradiation in zoster. Epidemiol Infect 2002 Dec;129(3):593-597. [Medline: 12558343]

52. Jardine A, Conaty SJ, Vally H. Herpes zoster in Australia: evidence of increase in incidence in adults attributable to varicella immunization? Epidemiol Infect 2011 May;139(5):658-665. [doi: 10.1017/S0950268810001949] [Medline: 20727248]

53. Hope-Simpson SE. The nature of herpes zoster: a long-term study and a new hypothesis. Proc R Soc Med 1965 Jan;58:9-20 [FREE Full text] [Medline: 14267505]

54. Toyama N, Shiraki K, Society of the Miyazaki Prefecture Dermatologists. Epidemiology of herpes zoster and its relationship to varicella in Japan: A 10-year survey of 48,388 herpes zoster cases in Miyazaki prefecture. J Med Virol 2009 Dec;81(12):2053-2058. [doi: 10.1002/jmv.21599] [Medline: 19856466]

55. Kim YJ, Lee CN, Lim C, Jeon WS, Park YM. Population-based study of the epidemiology of herpes zoster in Korea. J Korean Med Sci 2014 Dec;29(12):1706-1710 [FREE Full text] [doi: 10.3346/jkms.2014.29.12.1706] [Medline: 25469074]

56. Cooper M. The epidemiology of herpes zoster. Eye (Lond) 1987;1 ( Pt 3):413-421. [doi: 10.1038/eye.1987.63] [Medline: 3653445]

57. Korostil IA, Regan DG. Varicella-zoster virus in Perth, Western Australia: seasonality and reactivation. PLoS One 2016;11(3):e0151319 [FREE Full text] [doi: 10.1371/journal.pone.0151319] [Medline: 26963841]

58. Brisson M, Edmunds WJ, Law B, Gay NJ, Walld R, Brownell M, et al. Epidemiology of varicella zoster virus infection in Canada and the United Kingdom. Epidemiol Infect 2001 Oct;127(2):305-314. [Medline: 11693508]
Abbreviations
API: application programming interface
FDA: United States Food and Drug Administration
HZ: herpes zoster
NACI: Canadian National Advisory Committee on Immunization
NIH-NEI: National Institutes of Health National Eye Institute

Edited by M Focsa; submitted 20.02.18; peer-reviewed by N Bragazzi, G Rutherford; comments to author 16.03.18; revised version
received 19.03.18; accepted 20.03.18; published 02.05.18
Please cite as:
Berlinberg EJ, Deiner MS, Porco TC, Acharya NR
Monitoring Interest in Herpes Zoster Vaccination: Analysis of Google Search Data
JMIR Public Health Surveill 2018;4(2):e10180
URL: http://publichealth.jmir.org/2018/2/e10180/
doi: $\underline{10.2196 / 10180}$
PMID: $\underline{29720364}$


CElyse J Berlinberg, Michael S Deiner, Travis C Porco, Nisha R Acharya. Originally published in JMIR Public Health and Surveillance (http://publichealth.jmir.org), 02.05.2018. This is an open-access article distributed under the terms of the Creative Commons Attribution License (https://creativecommons.org/licenses/by/4.0/), which permits unrestricted use, distribution, and reproduction in any medium, provided the original work, first published in JMIR Public Health and Surveillance, is properly cited. The complete bibliographic information, a link to the original publication on http://publichealth.jmir.org, as well as this copyright and license information must be included. 